\title{
Improving Creativity through Social Media for Rural Women's Empowerment
}

\author{
Lina Siti Nurwahidah ${ }^{2}$, Cecep Dudung Julianto ${ }^{2}$, Zoni Sulaiman ${ }^{3}$ \\ \{linasiti@institutpendidikan.ac.id ${ }^{1}$, cecepdudung@institutpendidikan.ac.id ${ }^{2}$, \\ zonisulaiman@institutpendidikan.ac.id $\left.{ }^{3}\right\}$ \\ Institut Pendidikan Indonesia, Jl. Terusan Pahlawan No.32, Garut 44151 1,2,3
}

\begin{abstract}
Social media as one form of the 'new media' era makes it easy for humans to access various information without time and space limitations. Based on this notion, this study aimed to describe the use of social media to improve the creativity of rural women in maintaining their lives. The research method used was descriptive method. In collecting data, interview and observation techniques were employed. The results of this study indicated that after utilizing social media, the participants gained sufficient knowledge which could be seen from their ability to develop fresh ideas to modify traditional foods according to market share. In addition, they developed supporting traits to support their idea such as patience, diligence, effectively using time, risk taking, and reading market situations. From this study the researcher suggested that there must be coordination between policy stakeholders in the village, non-formal education authorities, and entrepreneurs.
\end{abstract}

Keyword: creativity, women's empowerment, social media.

\section{Introduction}

The development of the technology in the world is rapidly increasing towards the new media era. This new media includes the use of computers and communication technology [1]. This media has made people enter new lifestyles that cannot be separated from digital devices. The use of digital technology (social media, multimedia, and communication) with higher social interactions has penetrated almost every aspect of human life [2]. One of the examples of this phenomenon is the use of social media. Its daily use and development has changed the map of information distribution.

Social media has had a big impact on life. This product from the 'new media' digital era allows humans to communicate with each other anywhere, anytime, and with anyone. Social media users can access it using the internet network easily with affordable price or even free. Besides its use in communication aspect, social media has often been used to help social problems, for example, optimizing the marketing of small and medium enterprises (SMEs) [3].

These advantages can be used to help overcoming the problems of government policy regarding women empowerment. In reality, the realization of this government policy faces many obstacles [4] which are caused by: 
(1) the large number of illiterate women, which prevents them from accessing employment / business opportunities; (2) there is a cultural value belief that views women as housewives so that they do not need to seek economic life because it is men's duty; (3) the lagging level of women's education has an impact on the low quality of women's lives; (4) the existence of discrimination in both treatment and policy towards women in conducting productive business; (5) lack of a spirit of competitiveness and courage among women due to inequality in the treatment and the views of the community towards women, thereby reducing their level of achievement and participation in various fields of development; (6) limited opportunities given to women to actively participate in various fields of development, which made their creativity and innovation are not optimally developed.

All the limitations of these women must be a concern, because the role of women in rural areas is complex. They are resilient workers outside the home without ignoring their roles as wives and mothers at home. With this fact, the demand for improving both their attitudes and skills must be prioritized.

Based on the background above, the author had the research objective of utilizing social media as follows: (1) increasing knowledge and technology expertise through vocational skills; (2) disseminating knowledge and technology through vocational skills; and (3) fostering community creativity in solving problems by utilizing the potential resources and community organizations.

\section{Theoretical Framework}

\subsection{The Use of Social Media}

Social media is an internet-based application in the form of producing and consuming information both in text, audio, visual, and audiovisual that is used by humans to interact socially and economically without space and time limits [5]. The products from 'new media' in this digital era have had a big impact on life. Social media allows humans to communicate with each other anywhere, anytime, and with anyone. Social media users can access it using the internet network with less difficulty. Social media has the following characteristics. 1) Collectivity; 2) Connectivity; 3) Completeness; 4) Clarity; and 5) Collaboration.

\subsection{Rural Women's Empowerment}

Women's empowerment cannot be separated from the general concept of community empowerment. To be able to understand the concept of community empowerment we need to understand its style. Some features of empowerment are (1) human dignity - developing human dignity, potential, and energy; (2) Empowerment - empowering both individuals and groups; (3) participatory, and (4) fair [6]. Meanwhile, the philosophy of community empowerment includes: (1) independency, (2) always looking for and finding joint solutions, (3) having assistance (technically and practically), (4) democratic, and (5) supporting the emergence of local leadership.

The aspects of empowerment include physical, intellectual, economic, political, and cultural, thus empowerment includes total human development. Meanwhile, participatory and fair aspects include (1) having the same right to gain access to resources and social services, (2) concerning basic rights, (3) developing in equality, (4) profitable, (5) with regard to desire 
or even individual needs to take part in the common interest, (6) optimally utilize what has been created in this world, (7) more moral than legal, and (8) closely related to human needs.

One of the causes of women's powerlessness in society is gender inequality which drives the decline of women's roles and positions in society. Gender differences should not be a problem as long as they do not present gender inequality. But these gender differences actually create various injustices, both for men and women. Therefore, there are several important components that need to be considered in an effort to empower women, namely (1) strong organization and leadership, (2) knowledge of women's rights issues, (3) determining strategies, (4) large groups of participants or supporters, and (5) communication and education. Meanwhile, one of the efforts in empowering human resources, especially women, is through the cultivation and strengthening the spirit and practice of entrepreneurship.

\section{Method}

The purpose of this study was to describe the effect of using social media on the creativity of rural women in maintaining their lives. In this study, the author tried to collect data from a group of rural women and their system of thought in the present day by analyzing and classifying data from the observations and interviews. This method was used to get an idea of the activities of rural women in maintaining their lives. The data sources that we have taken are some mothers who have part time jobs as traditional food makers in a village in Garut, Indonesia.

\section{Result and Discussion}

From the results of observations and interviews with the participants, the following results can be stated.

Table 1. Observation finding on the use of social media in food production.

\begin{tabular}{cccc}
\hline Participants & Shape & Taste & Color \\
\hline P1 & Good & Very Good & Good \\
P2 & Good & Good & Good \\
P3 & Very Good & Good & Good \\
\hline
\end{tabular}

From the finding, it can be seen that the participants' ability to make traditional food after the use of social media is in the good to very good category. It was because their knowledge about the foods - the materials and the way to make it - increased which made the quality of the shape, taste, and color of the products they made better. 


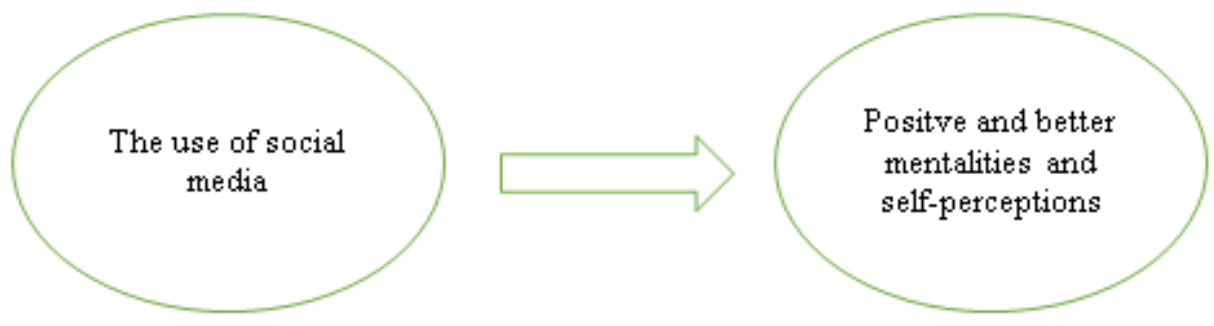

Fig. 1. The positive effects of using social media in affective aspects.

Figure 1 above shows that there are effects for affective aspects that make the participants more tenacious, patient, diligent, willing to take risks to increase production and income, participate, good at reading market situations, and can use time efficiently so they have a positive mentality towards work. This is in accordance with the benefits of social media [7], namely that social media communication will have an influence on (1) trust, values, and attitudes; (2) worldview; (3) social organizations; (4) human nature; (5) activity orientation; and (6) perceptions of self and others.

Furthermore, related to entrepreneurial attitudes, the participants also seemed enthusiastic to develop their business. Mental attitude in responding to food business such as selfconfidence, hard-working, independent, optimistic, looking at risk as part of success, responding to suggestions and criticism, innovative and creative, and future-oriented in carrying out its business could obviously be identified.

After the participants used social media, they had no difficulty in developing business because mass communication consists of messages transmitted to the target audience that are clear and widespread, using newspapers, magazines, television, radio, and the internet [8]. This resulted in positive impacts such as sufficient knowledge in planning, managing, seeking opportunities, and especially optimism to achieve a better future.

At the beginning of the study, from the results of observations and interviews appeared the desire of the participants to return to previous work, namely working in the fields or other part time jobs. They assumed that previous work also provides additional income for their daily lives. But with after they were given various explanations and motivation, they had the desire to be able to survive in developing their business in accordance with the abilities they have learned in technology literacy. Meanwhile, in the education program for making rengginang, it was found that the participants could develop their businesses in accordance with the skills held in groups, even though the scale was still small. They made rengginang with various flavors and forms and sold them in some stalls at Panawuan village also to cooperatives in the city.

Based on this finding, the researchers need to consider the various impacts after the program ended rather than merely providing the participants with only skills according to learning outcomes. It can be done by building conditions that support the successful use of the participants learning outcomes so that the improvement in the quality of the economy is not only at an individual level but quickly becomes larger level [9]. Thus, the problem of poverty can be overcome effectively and efficiently.

Based on the results of the research, it can be formulated a model for the implementation of this study that can be used as a reference in the future as follows.

At the pre-implementation stage, activities need to be carried out which include: (1) identification of needs carried out together with the target group; (2) supported by relevant and objective data; (3) the need for activities considering the relevance of employment; (4) the 
selection of training groups needs to consider various aspects such as interest, motivation, and commitment; (5) determining the facilitator by considering his/her competence and commitment; (6) learning facilities needs to be prepared by considering the principle of conformity, completeness, and ease of use; (7) learning materials are arranged in accordance with the objectives of the program, challenging, and integrated to the lives of the community members; and (8) before the implementation of the program, an assessment of the preparation stage needs to be carried out carefully.

At the implementation stage, it is necessary to carry out activities that include: (1) the process of learning activities carried out in various methods both theoretical and practical; (2) learning is done by emphasizing mastery learning; (3) the learning is carried out in an atmosphere of intimacy and equality; (4) utilization of learning resources that can be found in the community; (5) educational development services of the participants need to be developed; and (6) an assessment of all activities.

The post-implementation stage activities needs to be utilized that include: (1) assessment of learning outcomes considering the principles of relevance and objectivity; (2) assessment of learning outcomes using accurate data and valid and reliable instruments; (3) assessment needs to be carried out in collaboration with other competent parties to ensure the graduates' success is not merely a formality; (4) material and / or moral support is carried out in order to develop independency from the students in practicing their abilities; (5) cooperation networks with partners who act as patrons, mentors, assistants, recipients of labor, etc. need to be done; (6) forming or developing social institutions that have an empowerment function, which can be used as a place for guidance, business development and exchange of knowledge, and (7) assessments of the whole activities.

\section{Conclusion}

From the process of collecting, classifying, and analyzing, the researchers can conclude the following: (1) the use of social media can be utilized to improve vocational skills; (2) social media can be used to share knowledge and technology literacy by improving vocational skills; and (3) the use of social media can foster the creativity of the community in solving their life problems by utilizing the potential resources and community institutions. Activities that have been carried out by the participants run quite well which can be seen from the components of context, inputs, processes, and products. Meanwhile, on the impact component, they can practice the competencies they already have in the business world due to various factors that influence success both from the learning population, the learning process, and the environment. This condition shows that the implementation of activities can optimally reduce / overcome poverty levels quickly, thoroughly and beneficially.

The suggestion that the researchers can point out is the need for structured activities. This can be done by synergizing and coordinating the activities with related institutions, such as Non-formal Education institutions, Village, Village Unit Cooperatives or cooperatives / shops / supermarkets that can accommodate the products of their training. Therefore, the implementation of the activity program needs to be based on the idea that programs must produce quality graduates, market-oriented learning, and benefit both individuals and the community so that the stages of program implementation need to be carried out in a highquality manner. 


\section{References}

[1] Chen, D.-T., Wu, J., \& Wang, Y.-M.: Unpacking new media literacy. Journal on Systemics, Cybernetics and Informatics, Vol. 9, pp. 84-88 (2011).

[2] Eshet-Alkalai, Y., \& Soffer, O.: Guest editorial-navigating in the digital era: Digital literacy: Socio-cultural and educational aspects. Educational Technology \& Society, Vol 15, pp. 1-1 (2012)

[3] Siswanto, T.: Optimalisasi sosial media sebagai media pemasaran usaha kecil menengah. Liquidity Journal, Vol. 2, pp. 80-86 (2013)

[4] Direktorat Pembinaan Pendidikan Masyarakat.: Pemberdayaan perempuan (2012).[online]. Available at http:/paudni,kemdikbud.go.id/bindikmas/editorial/pemberdayaanperempuan. Downloaded on 12 Februari 2019.

[5] Julianto, C. D.: Keterampilan Literasi media sosial untuk menanamkan nilai kebhinekaan (2018).[online]. Available at http://proceedings.upi.edu/index.php/riksabahasa. Downloaded on 1 Maret 2018.

[6] Taruna, J. C. T.: Pendidikan nonformal dalam perspektif pemberdayaan masyarakat (2001). [online]. Available at http:/www.balaidesa.or.id/tukiman/htm. Downloaded on 1 Februari 2018.

[7] Baran, S. J. \& Dennis, K. D..: Mass communication theory: Foundations, Ferment and Future. Belmot: CA, Wadswoth, (2010)

[8] Adler, R. B. \& Rodman G.: Understanding human communication. New York: Oxford University Press, (2006)

[9] Abdulhak, I.: Strategi membangun motivasi dalam pembelajaran orang dewasa. Bandung: AGTA Manunggal Utama, (1996) 